\title{
Downregulation of estrogen receptor $\beta$ inhibits lung adenocarcinoma cell growth
}

\author{
WENJUAN CHEN ${ }^{1,2^{*}}$, BO XIN ${ }^{3 *}$, HAILIN PANG ${ }^{1}$, LE HAN $^{2}$, WEIWEI SHEN ${ }^{1}$, \\ ZHENG ZHAO $^{2}$, LIAN DUAN ${ }^{1}$, PEIPEI CAO ${ }^{1}$, LILI LIU $^{1}$ and HELONG ZHANG ${ }^{1}$ \\ ${ }^{1}$ Department of Oncology, Tangdu Hospital, The Air Force Medical University, Xi'an, Shaanxi 710038; \\ ${ }^{2}$ Department of Oncology, Tumor Hospital of Shaanxi Province, Xi'an, Shaanxi 710061; \\ ${ }^{3}$ Department of Oncology, No. 88 Hospital of People's Liberation Army, Tai'an, Shandong 271000, P.R. China
}

Received September 6, 2018; Accepted March 4, 2019

DOI: $10.3892 /$ or.2019.7044

\begin{abstract}
Estrogen receptor $\beta(E R \beta)$ is an important ER subtype in lung adenocarcinoma. However, the functions and mechanisms of ER $\beta$ have not been fully elucidated. The aim of the present study was to investigate the biological effects and relevant mechanisms of ER $\beta$ in lung adenocarcinoma. The protein expression of ER $\beta$ was found to be higher in lung adenocarcinoma tissues compared with that in adjacent non-cancerous tissues $(n=75, P<0.001)$. Of note, $E R \beta$ protein expression was significantly correlated with tumor size $(\mathrm{P}=0.018)$, lymph node metastasis $(\mathrm{P}=0.041)$, clinical stage $(\mathrm{P}=0.041)$ and differentiation $(\mathrm{P}<0.001)$. In addition, $\mathrm{ER} \beta$ protein expression in A549 cells was found to be higher compared with that in human bronchial epithelial cells (HBEs). Furthermore, knockdown of ER $\beta$ expression inhibited colony formation and cell invasion in vitro, whereas the number of metastatic tumors in the lungs of mice was decreased in vivo. Western blot analysis demonstrated that the expression of phosphorylated extracellular signal-regulated kinase (pERK), matrix metalloproteinase (MMP)-2 and MMP-9 was decreased by downregulation of ER $\beta$. Therefore, ER $\beta$ may play an important role in lung adenocarcinoma progression via the MEK/ERK signaling axis, and it may represent a novel therapeutic target for lung adenocarcinoma in the future.
\end{abstract}

\section{Introduction}

Lung cancer is the most common malignant tumor and one of the main causes of cancer-related mortality worldwide (1).

Correspondence to: Professor Helong Zhang, Department of Oncology, Tangdu Hospital, The Air Force Medical University, 569 Xinsi Road, Xi'an, Shaanxi 710038, P.R. China

E-mail: cnxazhl@163.com

\section{${ }^{*}$ Contributed equally}

Key words: lung adenocarcinoma, $17 \beta$-estradiol, estrogen receptor $\beta$, MEK/extracellular signal-regulated kinase
The 5-year survival rate is $\sim 15 \%$, and only $15-17 \%$ of patients diagnosed with distant metastasis survive for 1 year $(2,3)$. Adenocarcinoma is one of the major subtypes of non-small cell lung cancer (NSCLC), and lung adenocarcinoma patients frequently develop metastases (4). It is estimated that $>35 \%$ of patients with advanced lung adenocarcinoma develop distant metastases, resulting in shorter survival and poor quality of life (5). Conventional treatments, including chemotherapy, radiotherapy and bisphosphonates, have been shown to have limited efficacy (1). Hence, it is crucial to elucidate the mechanisms underlying lung adenocarcinoma progression.

Estrogen and progesterone receptors have been shown to play an important role in NCSLC, particularly lung adenocarcinoma (6). The incidence and mortality of lung cancer were found to be higher among women who receive hormone replacement therapy (7). The effects of estrogen are mediated via estrogen receptors (ER $\alpha$ and $\mathrm{ER} \beta)$ (8). Estrogen receptors are consistently found in lung cancer tissues and cell lines (particularly adenocarcinoma), mostly in the form of $\operatorname{Er} \beta$ (9). Hsu et al reported that estrogen promoted lung adenocarcinoma cell proliferation and migration via ER $\beta$, and high expression of ER $\beta$ was identified as an adverse prognostic factor in patients with lung adenocarcinoma (9). However, the detailed mechanism underlying ER $\beta$-mediated lung adenocarcinoma progression remains unclear.

The aim of the present study was to determine whether the expression of ER $\beta$ is higher in lung adenocarcinoma tissues, as well as observe the effects of its knockdown by lentivirus interference RNA on lung adenocarcinoma cell growth and invasion in vitro and in vivo.

\section{Materials and methods}

Immunohistochemical staining of ER $\beta$. Tissue microarray (TMA) assays were obtained from Superchip (Shanghai, China) and included 75 cases of tissues from lung adenocarcinoma and adjacent normal tissues (array ID: HLug-Ade150Sur-02). The recorded clinicopathological information included age, sex, tumor size, tumor location and TNM stage. Experiments were performed as described previously $(10,11)$. The tissue sections were de-paraffinized, rehydrated, and treated according to standard protocols (12). Polyclonal rabbit anti-ER $\beta$ antibody 
(dilution 1:50; cat. no. ab3577) was purchased from Abcam (Cambridge, UK) (13) and incubated at $4^{\circ} \mathrm{C}$ overnight.

Immunohistochemical assay. The stained tissue arrays were defined as one of nine degrees, according to the immunohistochemical scores reported $(10,11)$. Primarily, six degrees of proportional score for positive staining were assigned according to the proportion of positive tumor cells (0, none; $1,<1 / 100 ; 2,1-10 / 100 ; 3,10-30 / 100 ; 4,30-60 / 100$; and $5,>60 / 100)$. Thereafter, four degrees of intensity score were assigned according to the intensity of staining $(0$, none; 1 , weak; 2 , intermediate; and 3 , strong). The proportion and intensity scores were then added to yield a total score, which ranged from 0 to 8 . According to the total score, the cases were classified as low/negative expression (total score, $0-4$ ) and high expression (total score, 5-8). Final scores were confirmed in a double-blind manner by two independent pathologists.

Drugs and chemicals. The ER $\beta$ agonist diarylpropionitrile (DPN; CAS1428-67-7) and the ER $\alpha$ agonist propylpyrazoletriol (PPT; CAS263717-53-9) were purchased from Tocris Bioscience (Bristol, UK); 17ß-estradiol (E2; MFCD01074033) was purchased from Sigma-Aldrich; Merck KGaA (Darmstadt, Germany).

Cell lines and cell culture. The human lung adenocarcinoma cell line A549, the human breast cancer cell line MCF-7 and human bronchial epithelial (HBE) cells were preserved in our laboratory. The A549, MCF-7 and HBE cells were maintained in RPMI-1640 medium (C11875500B; Gibco, Thermo Fisher Scientific, Inc., Waltham, MA, USA) supplemented with $10 \%$ fetal bovine serum (FBS; Biochrom GmbH, Berlin, Germany). The cells were incubated at $37^{\circ} \mathrm{C}$ in a humidified atmosphere of $5 \% \mathrm{CO}_{2} / 95 \%$ air.

Western blot analysis. Cells were lysed for protein extraction. After being quantified, $25 \mu \mathrm{g}$ of protein was subjected to $10 \%$ SDS-polyacrylamide gel electrophoresis and transferred to polyvinylidene fluoride membranes. The membranes were then blocked in 5\% fat-free milk and incubated overnight at $4^{\circ} \mathrm{C}$ with rabbit polyclonal antibodies against ER $\beta$ (dilution 1:2,000; cat. no. ab3577), extracellular signal-regulated kinase (ERK)1/2 (dilution 1:500; cat. no. ab176640), pERK1/2 (dilution 1:500; cat. no. ab76299), matrix metalloproteinase (MMP)-2 (dilution 1:2,000; cat. no. ab37150), MMP-9 (dilution 1:2,000; cat. no. ab38898) and mouse monoclonal antibody against GAPDH (dilution 1:8,000; cat. no. ab8245), all purchased from Abcam. Next, the membranes were incubated with anti-rabbit/mouse secondary antibodies (cat. nos. GTX213110-10/GTX213111-01; GeneTex, Inc., Irvine, CA, USA). Finally, the content of the target proteins was determined by chemiluminescence (Pierce; Thermo Fisher Scientific, Inc.).

Cell proliferation assay. The MTT assay (Sigma-Aldrich; Merck KGaA) was conducted to determine cell proliferation. Briefly, A549 cells were seeded into 96-well plates (Corning Inc., Corning, NY, USA) at a density of $1 \times 10^{4}$ cells/well and treated with E2 $(10 \mathrm{nM})$, DPN $(10 \mathrm{nM})$ or PPT $(10 \mathrm{nM})$ for 0,24 , 48 and $72 \mathrm{~h}$, and added the same volume of phosphate-buffered saline (PBS) as the control group. At each time-point, $20 \mu 1$ MTT $(10 \mathrm{mg} / \mathrm{ml})$ was added to each well and successively incubated for another $4 \mathrm{~h}$ at $37^{\circ} \mathrm{C}$. After removing the supernatant, $150 \mu \mathrm{l}$ dimethylsulfoxide (S7020; Invitrogen; Thermo Fisher Scientific, Inc.) was added for $10 \mathrm{~min}$ to dissolve the formazan crystals. The absorbance was measured at $490 \mathrm{~nm}$ with a microplate reader (Multiskan MK3; Thermo Fisher Scientific, Inc.). Each experiment was performed in triplicate and repeated three times.

Cell infection. Short hairpin RNAs (shRNA1: GCATGGAAC ATCTGCTCAA; shRNA2: GCTGAATGCCCACGTGCTT; shRNA3: GCAAAGAGGGCTCCCAGAA) targeting ER $\beta$ (ER $\beta$-GV248-RNAi NM_001437, target sequence: GCAAAG AGGGCTCCCAGAA) and control shRNA (NC-GV248, target sequence: TTCTCCGAACGTGTCACGT) were obtained from Shanghai GeneChem Co., Ltd. (Shanghai, China). A549 cells were infected with the ER $\beta$-shRNA lentivirus to knock down ER $\beta$ expression, and NC-shRNA was used at the same time as a negative control group, according to the manufacturer's instructions. After $72 \mathrm{~h}$, green fluorescent protein indicated that the rate of infection was $\sim 90 \%$ at a multiplicity of infection of 10 . Stably transfected cells were then selected with puromycin for 2 weeks.

Reverse transcription-quantitative polymerase chain reaction (RT-qPCR) analysis. Total RNA of infected A549 cells was isolated from cells using TRIzol reagent (Invitrogen; Thermo Fisher Scientific, Inc.), according to the manufacturer's instructions. Total RNA (500 ng) was then reverse-transcribed into cDNA (Takara Bio, Inc., Otsu, Japan). RT-PCR was performed using SYBR Premix Ex Taq $^{\mathrm{TM}}$ II (Takara Bio, Inc.) and gene expression was quantified using the cycle quantification (Cq) method. The PCR primers were as follows: ER $\beta$ forward, GAT CATTGCTCCTCCTGAGC and reverse, CACCTTCACCGT TCCAGTTT; GAPDH forward, AGCACGGCTCCATATACA TACC and reverse, TGGACCACTAAAGGAGAAAGGT.

Colony formation assay. The infected A549 and control cells in the logarithmic growth phase were harvested and plated into 6-well plates (cat. no. A1098201; BioExcellence International Tech Co., Ltd.) at 500 cells/well. After incubation for 8 days, cell colonies $(>50$ cells) were stained with $0.25 \%$ crystal violet solution and their number was manually counted. Each experiment included three independent biological replicates and each was performed in triplicate.

Cell invasion assay. The invasive potential of the cells was measured using $8-\mu \mathrm{m}$ pore size Transwell inserts (Corning, Inc.). The infected A549 and control cells were resuspended in serum-free RPMI-1640 and then seeded in triplicates in the upper chamber covered with $70 \mu 1$ Matrigel (diluted in 1:8; Corning, Inc.). Medium (500 $\mu$ l) containing 10\% FBS was added to the bottom chamber to serve as the chemoattractant. After $24 \mathrm{~h}$, cells that had migrated to the lower chamber were fixed with 95\% ethyl alcohol and then stained with $0.5 \%$ crystal violet solution. Finally, the number of invading cells was counted in five random fields per sample and the mean was calculated. Each experiment included three independent biological replicates and each was performed in triplicate. 
Table I. Correlation of ER $\beta$ with the clinicopathological characteristics of the lung adenocarcinoma patients.

\begin{tabular}{|c|c|c|c|c|}
\hline \multirow[b]{2}{*}{ Characteristics } & \multicolumn{3}{|c|}{ ER $\beta$ expression } & \multirow[b]{2}{*}{ P-value } \\
\hline & $\mathrm{N}$ & Low, n (\%) & High, n (\%) & \\
\hline Tissue source & & & & $<0.0001$ \\
\hline Tumor & 75 & $6(11.5)$ & $69(70.4)$ & \\
\hline Adjacent & 75 & $26(88.5)$ & $49(29.6)$ & \\
\hline Age (years) & & & & 0.352 \\
\hline$<60$ & 32 & $11(37.9)$ & $22(45.7)$ & \\
\hline$\geq 60$ & 43 & $19(62.1)$ & $25(58.1)$ & \\
\hline Sex & & & & 0.200 \\
\hline M & 40 & $3(33.3)$ & $25(56.1)$ & \\
\hline $\mathrm{F}$ & 35 & $6(66.7)$ & $24(43.9)$ & \\
\hline Tumor size (mm) & & & & 0.018 \\
\hline$\leq 30$ & 31 & $7(77.8)$ & $24(36.4)$ & \\
\hline$>30$ & 44 & $2(22.2)$ & $42(63.6)$ & \\
\hline Location & & & & 0.356 \\
\hline Left & 31 & $5(55.6)$ & $26(39.4)$ & \\
\hline Right & 44 & $4(44.4)$ & $40(60.6)$ & \\
\hline Differentiation & & & & $<0.0001$ \\
\hline Well & 8 & $5(55.6)$ & $3(4.5)$ & \\
\hline Moderate & 51 & $3(33.3)$ & $48(72.7)$ & \\
\hline Poor & 16 & $1(11.1)$ & $15(22.7)$ & \\
\hline Lymph node metastasis & & & & 0.041 \\
\hline No & 27 & $6(66.7)$ & $21(31.8)$ & \\
\hline Yes & 48 & $3(33.3)$ & $45(68.2)$ & \\
\hline Stage & & & & 0.041 \\
\hline I-II & 43 & 8 (88.9) & $35(53.0)$ & \\
\hline III & 32 & $1(11.1)$ & $31(47.0)$ & \\
\hline
\end{tabular}

ER, estrogen receptor; $M$, male; F, female.

In vivo experiments. An experimental model of A549 cell lung metastasis was constructed to study the effects of $\mathrm{ER} \beta$ on lung adenocarcinoma in vivo. A total of 18 female NOD-SCID mice, aged 4 weeks and weighing 20-25 g, were purchased from Beijing HFK Bioscience Co. (Beijing, China). They were housed in a specific pathogen-free (SPF) laboratory animal environment (temperature, $22^{\circ} \mathrm{C}$; ventilation rate, $15 / \mathrm{h}$; light/dark cycle, $12 / 12 \mathrm{~h}$; food was sterilized with Cobalt-60 irradiation and water was autoclaved, and access to the food was ad libitum; tumor size not exceed $2.0 \mathrm{~cm}$ ) by professional breeders and randomly divided into three groups (6 mice/group). A549, A549-ER $\beta$-shRNA and A549-NC-shRNA cells $\left(1 \times 10^{6} / 200 \mu \mathrm{l}\right)$ were harvested, resuspended in PBS and injected via the tail vein. After 3 days, E2 $(0.1 \mathrm{mg} / \mathrm{kg})$ was subcutaneously injected once a week in a volume of $100 \mu \mathrm{l}$ per mouse. When the experimental mice developed symptoms such as lameness, joint stiffness, decreased exercise capacity, paraplegia, or an experiment for 42 days, the experiment required termination. The mice were sacrificed humanely in a transparent euthanasia device (ventilated $10 \%$ of isoflurane for $1 \mathrm{~min}$ before laying the mice, and constantly ventilated isoflurane for another 3 min after the mice were dead). The lungs were then excised and weighed; the number of the metastatic lesions larger than $0.5 \mathrm{~mm}$ in diameter on the surface of the lungs was counted, fixed in $10 \%$ formalin, embedded in paraffin, and sectioned for $H \& E$ staining.

All animal studies strictly abided by the Regulations on Animal Experimentation formulated by the Laboratory Animal Center of the Fourth Military Medical University (The Air Force Medical University) (Xi'an, China) and the present study was approved by the Animal Experimental Ethical Inspection Committee of this Center (no. 20170803).

Statistical analysis. Statistical analyses were conducted using SPSS 16.0 (SPSS Inc., Chicago, IL, USA). Wilcoxon rank sum test was used for immunohistochemical total scores analysis and the p-ERK/ERK ratio analysis was conducted by t-test. The other data were analyzed by one-way analysis of variance (ANOVA) with least significant difference (LSD) test as the post hoc test. P-values $<0.05$ were considered to indicate statistically ignificant differences. 
A


Figure 1. Estrogen receptor (ER) $\beta$ is overexpressed in lung adenocarcinoma tissues. (A) Representative immunohistochemical staining patterns of ER $\beta$ (magnification, $\mathrm{x} 400$; scale bar, $50 \mu \mathrm{m}$ ). (B) Total immunohistochemical score of the relative expression of ER $\beta$ in lung adenocarcinoma and adjacent non-cancerous tissues $(\mathrm{n}=75)$. ${ }^{*} \mathrm{P}<0.05$ compared with the adjacent non-cancerous tissues.

\section{Results}

Expression of ERß in lung adenocarcinoma patient samples and cell lines. Immunohistochemistry was used to evaluate the association of ER $\beta$ expression and pathological characteristics with a TMA that consisted of 75 paired lung adenocarcinoma specimens and corresponding normal samples. The expression of ER $\beta$ was observed in the cytoplasm. The correlations of ER $\beta$ expression with clinicopathological characteristics in the lung adenocarcinoma patients are presented in Table I and Fig. 1. We observed that the protein expression of ER $\beta$ was higher in lung adenocarcinoma tissues compared with that in adjacent non-cancerous tissues $(\mathrm{P}<0.001)$. Notably, ER $\beta$ protein expression was significantly correlated with tumor size $(\mathrm{P}=0.018)$, lymph node metastasis $(\mathrm{P}=0.041)$, clinical stage $(\mathrm{P}=0.041)$ and tumor differentiation $(\mathrm{P}<0.001)$. The results indicated that the expression of ER $\beta$ may be associated with the occurrence and progression of lung adenocarcinoma.

Furthermore, ER $\beta$ expression was compared among lung adenocarcinoma cells (A549), breast cancer cells (MCF-7) and HBE cells. MCF-7 cells were used as the positive control, and ER $\beta$ expression was found to be higher in A549 compared with that in MCF-7 and HBE cells (Fig. 2). The results indicated that ER $\beta$ is an important functional ER subtype in A549 cells.

E2 and DPN promote $A 549$ cell proliferation. The effects of E2, DPN and PPT on A549 and MCF-7 cells were investigated. MTT assay was conducted to evaluate cell proliferation. As shown in Fig. 3A, the proliferation of cells treated with E2 and DPN was markedly increased compared with that in the control groups while PPT which was effective for the 
A


Figure 2. (A and B) Expression of estrogen receptor (ER) $\beta$ in A549, MCF-7 and human bronchial epithelial (HBE) cells. MCF-7 cells were used as the positive control. Data are presented as the mean \pm standard deviation of three replicates. ${ }^{*} \mathrm{P}<0.05$ compared with HBE cells.

A

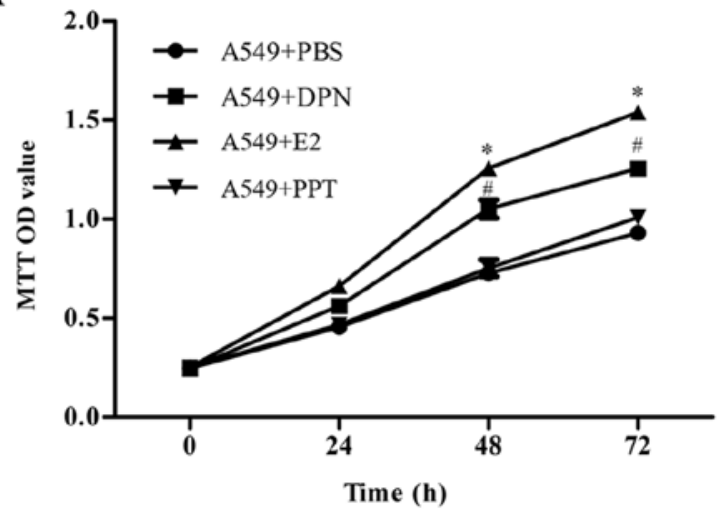

B



Figure 3. E2 and DPN promote A549 cell proliferation. Cells were treated with E2, DPN, PPT or PBS for 0,24,48 and $72 \mathrm{~h}$, and cell proliferation was evaluated using the MTT assay. (A) Effect of E2, DPN and PPT on the A549 cell proliferation. (B) Effect of E2, DPN and PPT on the MCF-7 cell proliferation. Data are presented as the mean \pm standard deviation. ${ }^{\mathrm{P}}<0.05$ (E2 group vs. control group) and ${ }^{\#} \mathrm{P}<0.05$ (DPN group vs. control group). DPN, diarylpropionitrile; PPT, propylpyrazoletriol; E2, 17ß-estradiol; PBS, phosphate-buffered saline.

A



B

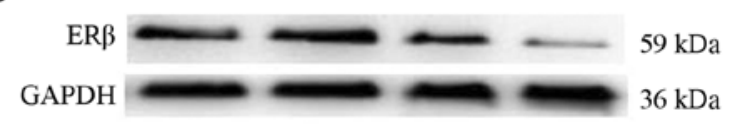

Figure 4. Effect of lentivirus-mediated knockdown of estrogen receptor (ER) $\beta$ expression in A549 cells. (A) The ER $\beta$ mRNA levels in A549 cells infected with ER $\beta$-shRNA or NC-shRNA were evaluated with reverse transcription-polymerase chain reaction analysis $\left({ }^{* *} \mathrm{P}=0.0145\right.$, ER $\beta$-shRNA3 compared with the NC-shRNA group). (B) Western blot analysis of ER $\beta$ protein expression in A549 cells infected with ER $\beta$-shRNA and NC-shRNA.

(AMCF-7 cells (Fig. 3B) did not obviously promote A549 cell proliferation; the E2-induced A549 cell proliferation may be mediated via $\mathrm{ER} \beta$ more than $\mathrm{ER} \alpha$.

Expression of ER $\beta$ decreases in cells stably transfected by lentivirus RNA interference. The lentivirus RNA interference technique was used to downregulate the expression of ER $\beta$.
Following cell infection and antibiotic screening for 2 weeks, the infection efficacy was confirmed by RT-PCR (Fig. 4A) and western blot analysis (Fig. 4B and C). ER $\beta$ was stably decreased by shRNA and the ER $\beta-G V 248$-RNAi\#3 was the most effective one, thus we named it as ER $\beta$-shRNA for the following tests. The results indicated that ER $\beta$ expression was suppressed by ER $\beta$-shRNA. 
A
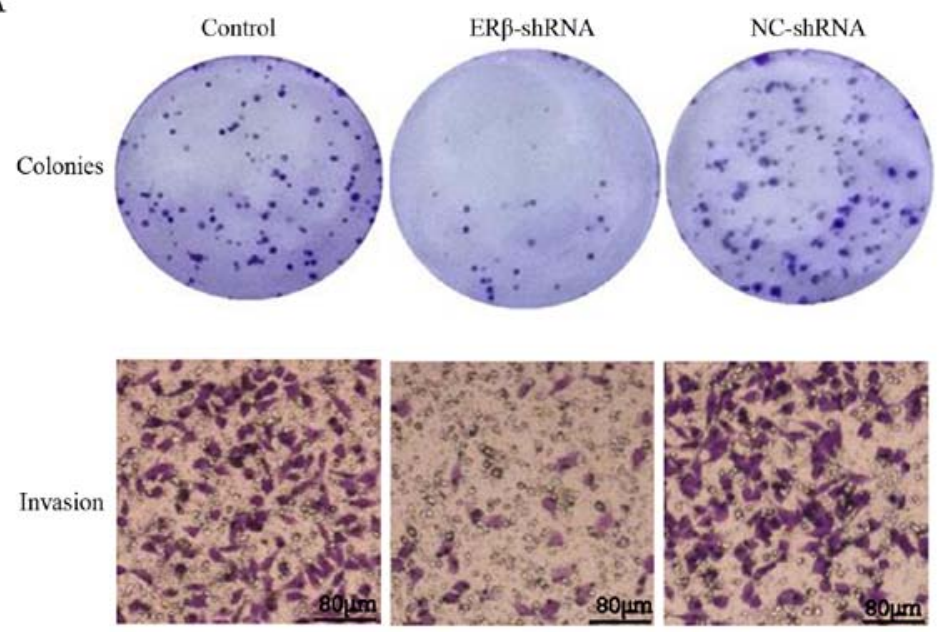

B

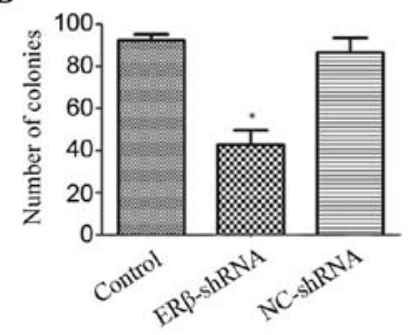

C



$\mathrm{D}$


Figure 5. Downregulation of estrogen receptor (ER $\beta$ ) expression inhibits colony formation and invasion of A549 cells in vitro. (A) Representative images of cell colony formation and invasion. (B) The number of colonies was calculated. (C) The number of invading cells was calculated (magnification, x100). (D) Western blot analysis of the expression of extracellular signal-regulated kinase (ERK), pERK, matrix metalloproteinase (MMP)-2 and MMP-9. GAPDH was used as the endogenous control. (E) pERK/ERK ratio was analyzed and data are presented as the mean \pm standard deviation of three replicates. ${ }^{*} \mathrm{P}<0.05$ or ${ }^{* *} \mathrm{P}<0.01$, compared with the NC-shRNA group. NC, negative control.

Downregulation of ERß expression inhibits colony formation and invasion of A549 cells in vitro. The effects of ER $\beta$-shRNA on A549 cells were examined. As shown in Fig. 5A-D, colony formation and cell invasion assays demonstrated that ER $\beta$-shRNA inhibited A549 cell proliferation and invasion compared with NC-shRNA and control $(\mathrm{P}<0.05)$. Mechanistically, ER $\beta$ knockdown suppressed the expression of pERK, MMP-2 and MMP-9 (Fig. 5E; P<0.05). These findings indicate that ER $\beta$ is a functional mediator. Therefore, knockdown of ER $\beta$ expression inhibited A549 cell proliferation and invasion via downregulation of pERK, MMP-2 and MMP-9.

Downregulation of ER $\beta$ expression suppresses lung metastasis of A549 cells in vivo. To investigate whether downregulation of ER $\beta$ expression may serve as a therapeutic target for lung adenocarcinoma, an experimental lung metastatic mouse model was constructed. In vivo lung metastasis assay demonstrated that downregulation of ER $\beta$ expression was associated with fewer metastatic tumors and lower lung weight compared with the control (Fig. 6). These results indicated that downregulation of ER $\beta$ may inhibit tumor growth and lung metastasis in vivo.

\section{Discussion}

Estrogen and ERs are considered to play an important role in lung carcinogenesis (14). Several studies have demonstrated that ER $\beta$ is the predominant ER in lung cancer tissue and tumor cell lines, particularly adenocarcinoma $(15,16)$. It was previously reported that estrogen promotes lung adenocarcinoma cell proliferation and migration via ER $\beta$ (11). However, the detailed mechanism underlying ER $\beta$-mediated lung adenocarcinoma progression remains unclear. The present study was designed to investigate the biological effects and mechanism of action of ER $\beta$ in lung adenocarcinoma.

To determine the association between ER $\beta$ and clinicopathological characteristics in lung adenocarcinoma, immunohistochemistry was used to evaluate the expression of ER $\beta$ in TMA, which included 75 tumor and adjacent normal tissues from patients with lung adenocarcinoma. A higher ER $\beta$ expression was detected in lung adenocarcinoma specimens compared with adjacent non-cancerous tissues. Notably, ER $\beta$ protein expression was found to be significantly correlated with tumor size $(\mathrm{P}=0.018)$, lymph node metastasis $(\mathrm{P}=0.041)$, clinical stage $(\mathrm{P}=0.041)$ and tumor differentiation $(\mathrm{P}<0.001)$, 
A



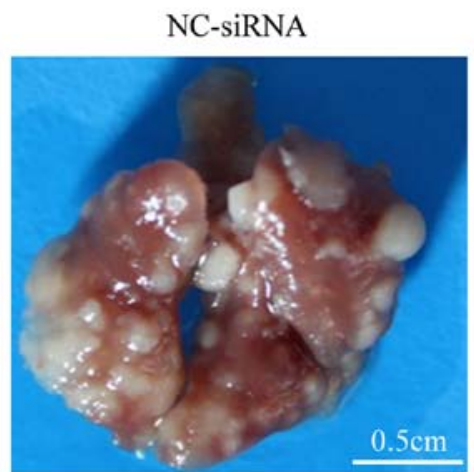

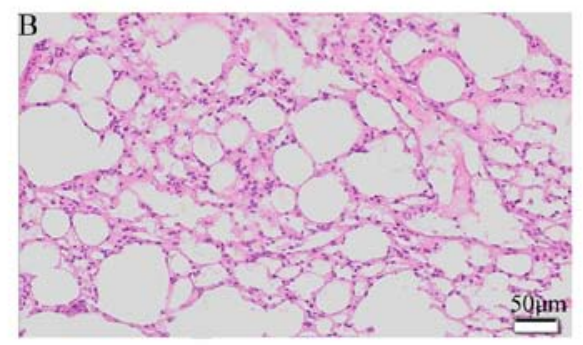

Normal lung tissue

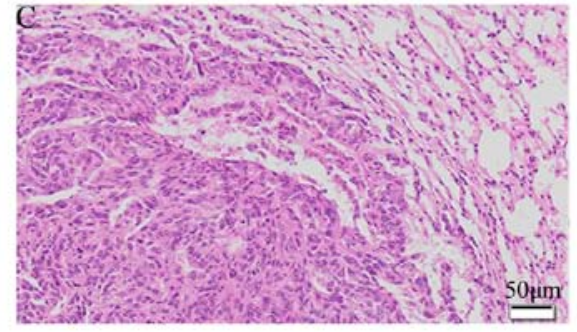

Tumor lung tissue

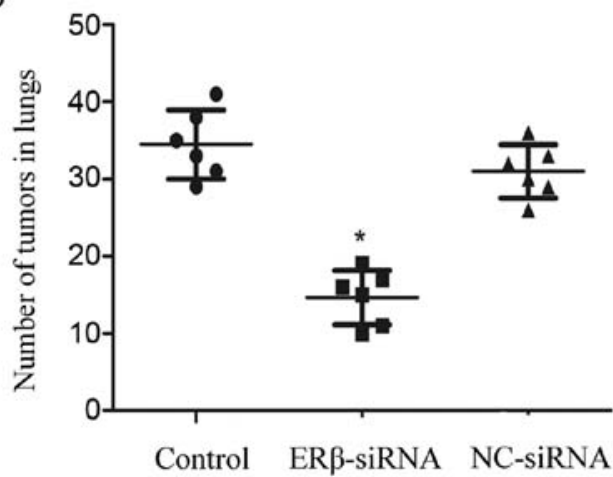

E

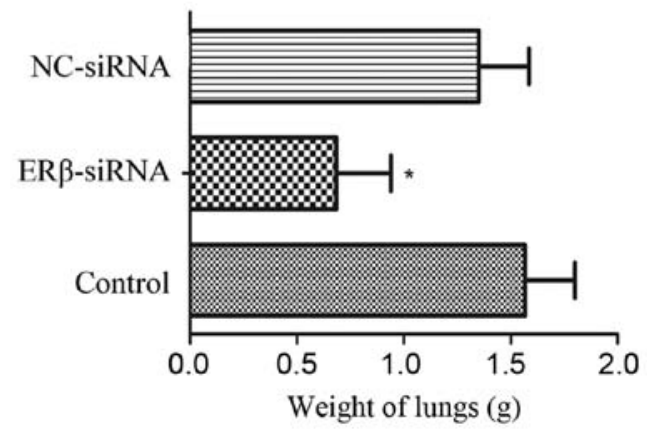

Figure 6. Downregulation of estrogen receptor (ER) $\beta$ expression suppresses lung metastasis of A549 cells in vivo. (A) Representative images of the lungs removed after treatment ( $\mathrm{n}=6$ /group). (B) Representative pathological image of normal lung tissue (magnification, $\mathrm{x} 200$ ). (C) Representative pathological image of metastatic tumors in the lungs (magnification, x100). (D) Quantification of metastatic tumors in the lungs of each group at 4 weeks after treatment. (E) Quantification of lung weight at 4 weeks after treatment. Data are presented as the mean \pm standard deviation of three replicates. "P $<0.05$, compared with control and NC-shRNA groups. NC, negative control.

suggesting that ER $\beta$ plays an important role in the occurrence and development of lung adenocarcinoma. Our findings were similar to those of Luo et al, who reported that ER $\beta$ overexpression promotes the progression of NSCLC (16).

Our findings in vitro were in agreement with the TMA results. ER $\beta$ expression was higher in the A549 cell line compared with that in HBE cells. ER $\beta$ was identified as the important ER subtype in lung adenocarcinoma cells. MTT assay was used to investigate whether the effects of E2 are mediated via ER $\alpha$ or ER $\beta$. The results indicated that $\mathrm{E} 2$ induced lung adenocarcinoma cell proliferation via ER $\beta$. These results are supported by the findings of Fan et al (17) and Warner and Gustafsson (18), who reported that $\mathrm{ER} \alpha$ was not the main mediator of transcriptional responses to E2 in NSCLC cells, but $\operatorname{ER} \beta$ was more likely to be the primary type in lung tumor tissues and cell lines, and that estrogen-dependent responses in
NSCLC cells are principally mediated by ER $\beta$. Furthermore, we demonstrated that downregulation of ER $\beta$ expression inhibited colony formation and invasion of A549 cells. In vivo, we constructed an experimental lung metastatic mouse model. The lung metastasis assay demonstrated that downregulation of ER $\beta$ expression was associated with fewer metastatic tumors and lower lung weight compared with the control group. Our results are consistent with those of Fan et al, who reported that estrogen and DPN promote lung metastasis of A549 cells (17). Fan et al's study revealed that estrogen induced lung cancer metastasis through the ER $\beta / \mathrm{MMP}-2$ axis. However, in the present study, MMP-9 was identified as a novel target gene of ER $\beta$. Thus, ER $\beta$ may promote lung cancer metastasis not only through MMP-2, but also through MMP-9. The development of lung adenocarcinoma is a complex multistep process. The ERK signaling pathway plays an important role in lung cancer cell proliferation 
and invasion. Therefore, the protein expression of ERK and pERK was determined in A549-ER $\beta$-shRNA cells. The results revealed that downregulation of ER $\beta$ expression decreased pERK expression levels. This finding suggested that downregulation of ER $\beta$ expression inhibited the proliferation and invasion of A549 cells through suppressing the phosphorylation of ERK. ERs also regulate gene expression through binding to other transcription factors, such as the activator protein 1 (AP-1) (19), the most important structural components of which are c-Jun and c-Fos. In addition, MMP is crucial for malignant tumor metastasis (20,21), particularly MMP-2 and MMP-9.

Taken together, the findings of the present study indicate that ER $\beta$ may promote lung adenocarcinoma growth and metastasis through the MEK/ERK signaling pathway and MMP-2/MMP-9 expression, and therefore, hold promise as a novel therapeutic target for lung adenocarcinoma.

\section{Acknowledgements}

The authors would like to thank all the colleagues of the Oncology Research Center for their comments on earlier versions of this manuscript.

\section{Funding}

The present study was supported by the National Natural Science Foundation of China (nos. 81272348, 81572814, 81572251) and the Natural Science Foundation of Shanxi, China (no. 2018JM7095).

\section{Availability of data and materials}

All data generated or analyzed during this study are included in this published article.

\section{Authors' contributions}

HZ designed the study. WC and BX performed the immunohistochemical assay and all the in vitro experiments and collected the data. HP, LH and WS conducted the animal experiments and collected the data. PC, LD, ZZ and LL analyzed the data and performed the relative statistical analysis. ZZ and LL provided guidance during the study. WC contributed to the writing of the manuscript. All authors have read and approved the final version of this manuscript and agree to be accountable for all aspects of the research in ensuring that the accuracy or integrity of any part of the work are appropriately investigated and resolved.

\section{Ethics approval and consent to participate}

All animal studies strictly abide by the Regulations on Animal Experimentation formulated by the Laboratory Animal Center of the Fourth Military Medical University (The Air Force Medical University) (Xi'an, China) and this study was approved by the Animal Experimental Ethical Inspection Committee of this Center (no. 20170803).

\section{Patient consent for publication}

Not applicable.

\section{Competing interests}

The authors declare that they have no competing interests.

\section{References}

1. Zamay TN, Zamay GS, Kolovskaya OS, Zukov RA, Petrova MM, Gargaun A, Berezovski MV and Kichkailo AS: Current and prospective protein biomarkers of lung cancer. Cancers 9: E155, 2017.

2. Fiorentino FP, Macaluso M, Miranda F, Montanari M, Russo A Bagella L and Giordano A: CTCF and BORIS regulate $R b 2 / p 130$ gene transcription: A novel mechanism and a new paradigm for understanding the biology of lung cancer. Mol Cancer Res 9: 225-233, 2011.

3. Blandin Knight S, Crosbie PA, Balata H, Chudziak J, Hussell T and Dive C: Progress and prospects of early detection in lung cancer. Open Biol 7: 170070, 2017.

4. Ren G, Esposito M and Kang Y: Bone metastasis and the metastatic niche. J Mol Med 93: 1203-1212, 2015.

5. Zang L, Ma M, Hu J, Qiu H, Huang B and Chu T: The effects of lung and prostate cancer bone metastasis on serum osteoprotegerin levels: A meta-analysis. Sci Rep 5: 18324, 2015.

6. Siegfried JM and Stabile LP: Estrongenic steroid hormones in lung cancer. Semin Oncol 41: 5-16, 2014.

7. Chlebowski RT, Schwartz AG, Wakelee H, Anderson GL, Stefanick ML, Manson JE, Rodabough RJ, Chien JW, Wactawski-Wende J, Gass $M$ and Women's Health Initiative Investigators: Oestrogen plus progestin and lung cancer in postmenopausal women (Women's Health Initiative trial): A post-hoc analysis of a randomised controlled trial. Lancet 374: 1243-1251, 2009.

8. Sims NA, Clément-Lacroix P, Minet D, Fraslon-Vanhulle C, Gaillard-Kelly M, Resche-Rigon M and Baron R: A functional androgen receptor is not sufficient to allow estradiol to protect bone after gonadectomy in estradiol receptor-deficient mice. J Clin Invest 111: 1319-1327, 2003.

9. Hsu LH, Liu KJ, Tsai MF, Wu CR, Feng AC, Chu NM and Kao SH: Estrogen adversely affects the prognosis of patients with lung adenocarcinoma. Cancer Sci 106: 51-59, 2015.

10. Kawai H, Ishii A, Washiya K, Konno T, Kon H, Yamaya C, Ono I, Minamiya Y and Ogawa J: Estrogen receptor alpha and beta are prognostic factors in non-small cell lung cancer. Clin Cancer Res 11: 5084-5089, 2005.

11. Allred DC, Harvey JM, Berardo M and Clark GM: Prognostic and predictive factors in breast cancer by immunohistochemical analysis. Mod Pathol 11: 155-168, 1998.

12. Liu Y, Yan X, Liu N, Zhou J, Liu J, Pang H, Cao J, Liu Y, Wang Y, Liu L and Zhang H: Lentivirus-delivered ZEB-1 small interfering RNA inhibits lung adenocarcinoma cell growth in vitro and in vivo. J Cancer Res Clin Oncol 138: 1329-1338, 2012.

13. Andersson S, Sundberg M, Pristovsek N, Ibrahim A, Jonsson P, Katona B, Clausson CM, Zieba A, Ramström M, Söderberg O, et al: Insufficient antibody validation challenges oestrogen receptor beta research. Nat Commun 8: 15840, 2017.

14. Hsu LH, Chu NM and Kao SH: Estrogen, estrogen receptor and lung cancer. Int J Mol Sci 18: 1713, 2017.

15. Mah V, Marquez D, Alavi M, Maresh EL, Zhang L, Yoon N, Horvath S, Bagryanova L, Fishbein MC, Chia D, et al: Expression levels of estrogen receptor beta in conjunction with aromatase predict survival in non-small cell lung cancer. Lung Cancer 74: 318-325, 2011.

16. Luo Z, Wu R, Jiang Y, Qiu Z, Chen W and Li W: Overexpression of estrogen receptor beta is a prognostic marker in non-small cell lung cancer: A meta-analysis. Int J Clin Exp Med 8: 8686-8697, 2015.

17. Fan S, Liao Y, Liu C, Huang Q, Liang H, Ai B, Fu S and Zhou S: Estrogen promotes tumor metastasis via estrogen receptor beta-mediated regulation of matrix-metalloproteinase-2 in non-small cell lung cancer. Oncotarget 8: 56443-56459, 2017.

18. Warner $M$ and Gustafsson JA: The role of estrogen receptor beta (ERbeta) in malignant diseases--a new potential target for antiproliferative drugs in prevention and treatment of cancer. Biochem Biophys Res Commun 396: 63-66, 2010.

19. Prusty BK and Das BC: Constitutive activation of transcription factor AP-1 in cervical cancer and suppression of human papillomavirus (HPV) transcription and AP-1 activity in HeLa cells by curcumin. Int J Cancer 113: 951-960, 2005.

20. Zhao XZ, Liu Y, Zhou LJ, Wang ZQ, Wu ZH and Yang XY: Role of estrogen in lung cancer based on the estrogen receptor-epithelial mesenchymal transduction signaling pathways. OncoTargets Ther 8: 2849-2863, 2015.

21. Valastyan S and Weinberg RA: Tumor metastasis: Molecular insights and evolving paradigms. Cell 147: 275-292, 2011. 